\title{
Effect of Zero Budget Natural Farming and Conventional Farming Systems on Biological Properties of Soil
}

\author{
Abdul Wakil Barakzai ${ }^{*}$, Rajeshwar Singh Chandel ${ }^{1}$, Sudhir Verma ${ }^{2}$, PremLal Sharma ${ }^{1}$, \\ Narendra Kumar Bharat ${ }^{3}$, Maneesh Pal Singh ${ }^{1}$ and Panma Yankit ${ }^{1}$ \\ ${ }^{1}$ Department of Entomology, ${ }^{2}$ Department of Soil Science and Water Management, \\ ${ }^{3}$ Department of Plant Pathology, Dr. Yashwant Singh Parmar University of Horticulture and \\ Forestry, Nauni, Solan, Himachal Pradesh (India) \\ *Corresponding author
}

\section{A B S T R A C T}

\section{Keywords}

Natural Farming, Conventional Farming, Organic formulations, Soil micro flora, Microarthropods

\section{Article Info}

\section{Accepted:}

10 January 2021 Available Online: 10 February 2021
The present study was conducted to study the biological properties of soil under zero budget natural farming (ZBNF) system, where only indigenous cow urine and dung based on-farm produced formulations viz. jeevamrit, beejamrit and ghanjeevamrit were used, in comparison to conventional farming (CF) practices with recommended fertilizer and pesticide doses in cauliflower ecosystem. ZBNF resulted in higher population of microflora. The population of bacteria, fungus and actinomycetes under ZBNF increased over the cropping period by $11.36,2.04$ and 8.72 in $2018-19$, and $23.69,12.04$ and 24.83 per cent in 2019-20, respectively, which was more than that under CF system 8.23, 2.44 and 3.34 per cent in 2018-19 and 12.87, 2.13 and 8.87 per cent in 2019-20, respectively. Activity of soil enzymes viz. dehydrogenase, phosphatase and urease under ZBNF increased by 3.01, 0.81, 3.84and 14.73, 1.42 and 14.01per cent, during 2018-19 and 201920respectively, which was much higher as compared to the CF system, where respective increase in enzymatic activity was $1.85,0.98,2.51$ and $3.38,1.37$ and 5.08 per cent during 2018-19 and 2019-20. An increment recorded in arthropods population. The increase in Hymenoptera, Hemiptera, Coleoptera, Isoptera, and Isopoda was 66.6, 0, 100, 33.3 and 200 per cent in ZBNF system, while in CF system, only Hymenoptera, Isoptera, and Isopodashowed an increase of 50, 50, and 100 per cent during first year experiment. During the second year also ZBNF showed higher increase in the arthropods population.

\section{Introduction}

Soil biological properties are important indicators of soil health. Most of fertile soils are rich in the population of both flora and fauna. Arthropods, fungus, bacteria, actinomycetes are major soil biological components those enrich the soil with various enzymes and increase the soil fertility (Siromani et al., 2013, Zhen et al., 2014 and Henneron et al., 2015). Indiscriminate use of agro-chemicals (toxic herbicides, insecticides, fertilizers) post green revolution has adversely impacted soil biological properties (Daikh et al., 2016; Ghosal and Hati 2019). It is a fact that deterioration of soil biological parameters 
leads to loss of soil fertility and decreasing yield (Singh and Lal, 2001). Various indigenous formulations such as cow urine and dung based Beejamrit, Jeevamrit and Panchgavya have shown their beneficial effects on soil biological properties (Shubha et al., 2014 and Sreenivasa et al., 2009), and are getting popular among farmers. Beejamrit, ghanjeevamrit and jeevamrit contain a lot of microbial properties and increase the soil micro flora with drastic increase in different soil enzymes. These formulations are rich in bacteria, fungus and actinomycetes population which not only provide basic soil conditioning but also have long lasting effect that leads to improvement in other soil biodiversity like soil arthropods, earthworms and other beneficiary fauna. Cow urine and dung based products are highly effective in improving the soil properties, and they increases the population of beneficial bacteria and fungus which act as antagonist against the plant pathogenic microorganisms (Gangadhar et al., 2020). Similarly these formulations also increase the beneficial arthropods predators in soil that lowers the pest population. In present investigation we observed the effect of beejamrit, ghanjeevamrit and jeevamrit and other organic amendments on soil flora and fauna in comparison with conventional farming practices.

\section{Materials and Methods}

Experiment was carried out at Model Farm, Zero Budget Natural Farming (ZBNF) system and the Experimental Farm of Entomology, Dr.Y.S. Parmar University of Horticulture and Forestry, Nauni, Solan, Himachal Pradesh, during the years 2018-19 and 201920. Cauliflower (PSBK-1) was raised in Conventional Farming (CF) system with recommended doses of fertilizers, viz. urea @ $300 \mathrm{~kg}$, SSP @ 675kg and MOP @ 85kg. Full dose of SSP, MOP and one-third of urea were applied at the time of transplanting. Same variety of cauliflower was grown in ZBNF system along with pea (dicot), coriander (cash crop) and mustard (trap crop) were sown as per the geometry in each plot with central row of pea than two rows of cauliflower, two rows of coriander and two marginal rows of Indian mustard. These were treated with beejamrit, jeevamrit and ghanjeevamrit. Randomly seven soil samples were taken from each field using soil auger up to $10 \mathrm{~cm}$ depth. These were used to determine the micro-flora and enzymatic activity in soil. Bacteria, fungi and actinomycetes were counted $(\mathrm{CFU} / \mathrm{ml})$ by plating $0.1 \mathrm{ml}$ of suitable dilution on separate plates, incubated at $28 \pm 2^{\circ} \mathrm{C}$ and cultured in Nutrient agar, Potato dextrose agar and Kenknight and Munaier medium (Subba, 1999). Soil enzyme dehydrogenase (Thimmaiah, 1999), soil Phosphatase (Tabatabai and Bremner, 1969) and urease (Thimmaiah, 1999) activities were determined. For soil arthropods seven random samples were obtained by inserting iron cylinder cores (10 cm length and $12 \mathrm{~cm}$ wide) in the soil. Arthropods were collected using the berlese-funnel method and counted after identification (Parisi et al., 2005 and Bano and Roy, 2016). All parameters were recorded before sowing and after harvest of the crop in both farming systems during both the years.

\section{Results and Discussion}

\section{Effect of farming systems on soil microbial population}

Notable changes in bacterial population were recorded in both systems. During 2018-19, bacterial population increased from $16.29 \mathrm{cfu}$ $\mathrm{g}^{-1}$ to $18.14 \mathrm{cfu} \mathrm{g}^{-1}$ in ZBNF system, while in CF system, it increased from $13.86 \mathrm{cfu} \mathrm{g}^{-1}$ to $15 \mathrm{cfu} \mathrm{g}^{-1}$. The per cent increase in bacterial population was $(11.36 \%)$ in ZBNF system, as compared to $8.23 \%$ in CF (Table 1), and during 2019-20, bacterial population increased from $19.29 \mathrm{cfu} \mathrm{g}^{-1}$ to $23.86 \mathrm{cfu} \mathrm{g}^{-1}$ 
in ZBNF system, while in CF system, it increased from $16.71 \mathrm{cfu} \mathrm{g}^{-1}$ to $18.86 \mathrm{cfu} \mathrm{g}^{-1}$. The increase in bacterial population was 23.69 per cent in ZBNF system, as compared to $12.87 \%$ in CF (Table 2). Similar results were also recorded in case of fungus and actinomycetes population. During 2018-19, fungal population increased from $6.86 \mathrm{cfu} \mathrm{g}$ ${ }^{1}$ to $7.00 \mathrm{cfu}^{-1}$ in ZBNF system, while in CF system, it increased from $6.14 \mathrm{cfu} \mathrm{g}^{-1}$ to 6.29 cfu $\mathrm{g}^{-1}$. The per cent increase was almost similar in ZBNF (2.04\%) and CF (2.44\%). In 2019-20, population increased from $7.14 \mathrm{cfu}$ $\mathrm{g}^{-1}$ to $8.00 \mathrm{cfu} \mathrm{g}^{-1}$ in ZBNF system, while in CF system, it increased from $6.57 \mathrm{cfu} \mathrm{g}^{-1}$ to
$6.71 \mathrm{cfu} \mathrm{g}^{-1}$. The per cent increase in fungi population was higher $(12.04 \%)$ in ZBNF system, as compared to CF (2.13\%) (Table 2). The actinomycetes population during 2018-19 increased from $16.29 \mathrm{cfu} \mathrm{g}^{-1}$ to $17.71 \mathrm{cfu} \mathrm{g}^{-1}$ in ZBNF system, while in CF system, it increased from $12.86 \mathrm{cfu} \mathrm{g}^{-1}$ to $13.29 \mathrm{cfu} \mathrm{g}^{-1}$. The per cent increase was higher in ZBNF (8.72\%) as compared to CF (3.34\%). During 2019-20, population increased from $20.14 \mathrm{cfu}$ $\mathrm{g}^{-1}$ to $25.14 \mathrm{cfu} \mathrm{g}^{-1}$ in ZBNF system, while in CF system, it increased from $14.43 \mathrm{cfu} \mathrm{g}^{-1}$ to $15.71 \mathrm{cfu}^{-1}$. The per cent increase was $24.83 \%$ in ZBNF system, as compared to $8.87 \%$ in CF (Table 2).

Table.1 Viable microbial count under ZBNF and CF systems during 2018-19

\begin{tabular}{|c|c|c|c|c|c|c|}
\hline \multirow[t]{3}{*}{ Viable microbes } & \multicolumn{6}{|c|}{ Farming systems } \\
\hline & \multicolumn{2}{|c|}{ ZBNF } & \multirow{2}{*}{ 苞 } & \multicolumn{2}{|c|}{$\mathbf{C F}$} & \multirow{2}{*}{ 总 } \\
\hline & $\begin{array}{l}\text { Before } \\
\text { sowing }\end{array}$ & $\begin{array}{c}\text { After } \\
\text { harvest }\end{array}$ & & $\begin{array}{l}\text { Before } \\
\text { sowing }\end{array}$ & $\begin{array}{c}\text { After } \\
\text { harvest }\end{array}$ & \\
\hline $\begin{array}{c}\text { Bacteria } \\
\left.\text { (x } 10^{8} \mathrm{cfu}^{-1}{ }^{-1} \text { soil }\right)\end{array}$ & 16.29 & 18.14 & 11.36 & 13.86 & 15.00 & 8.23 \\
\hline 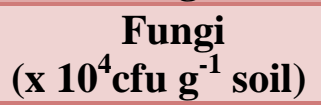 & 6.86 & 7.00 & 2.04 & 6.14 & 6.29 & 2.44 \\
\hline $\begin{array}{r}\text { Actinomycetes } \\
\text { (x 10 } \\
\text { cffu g }^{-1} \text { soil) }\end{array}$ & 16.29 & 17.71 & 8.72 & 12.86 & 13.29 & 3.34 \\
\hline
\end{tabular}

Table.2 Viable microbial count under ZBNF and CF systems during 2019-20

\begin{tabular}{|c|c|c|c|c|c|c|}
\hline \multirow[t]{3}{*}{ Viable microbes } & \multicolumn{6}{|c|}{ Farming systems } \\
\hline & \multicolumn{2}{|c|}{ ZBNF } & \multirow[b]{2}{*}{ 兽 } & \multicolumn{2}{|c|}{$\mathbf{C F}$} & \multirow[b]{2}{*}{ 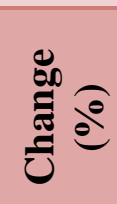 } \\
\hline & $\begin{array}{l}\text { Before } \\
\text { sowing }\end{array}$ & $\begin{array}{c}\text { After } \\
\text { harvest }\end{array}$ & & $\begin{array}{l}\text { Before } \\
\text { sowing }\end{array}$ & $\begin{array}{c}\text { After } \\
\text { harvest }\end{array}$ & \\
\hline $\begin{array}{c}\text { Bacteria } \\
\left(\times \mathbf{1 0}^{8} \mathrm{cfu}^{-1} \text { soil) }\right.\end{array}$ & 19.29 & 23.86 & 23.69 & 16.71 & 18.86 & 12.87 \\
\hline $\begin{array}{c}\text { Fungi } \\
\left(\times 10^{4} \mathrm{cfu}^{-1} \text { soil }\right)\end{array}$ & 7.14 & 8.00 & 12.04 & 6.57 & 6.71 & 2.13 \\
\hline $\begin{array}{r}\text { Actinomycetes } \\
\left(x 1^{3} \text { cfu g }^{-1} \text { soil) }\right.\end{array}$ & 20.14 & 25.14 & 24.83 & 14.43 & 15.71 & 8.87 \\
\hline
\end{tabular}


Table.3 Soil enzymatic activities under ZBNF and CF systems during 2018-19

\begin{tabular}{|c|c|c|c|c|c|c|}
\hline \multirow[t]{3}{*}{ Enzymes } & \multicolumn{6}{|c|}{ Farming systems } \\
\hline & \multicolumn{2}{|c|}{ ZBNF } & \multirow{2}{*}{ 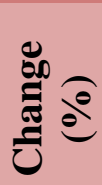 } & \multicolumn{2}{|c|}{ CF } & \multirow{2}{*}{ 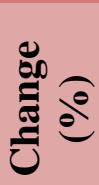 } \\
\hline & $\begin{array}{l}\text { Before } \\
\text { sowing }\end{array}$ & $\begin{array}{c}\text { After } \\
\text { harvest }\end{array}$ & & $\begin{array}{l}\text { Before } \\
\text { sowing }\end{array}$ & $\begin{array}{c}\text { After } \\
\text { harvest }\end{array}$ & \\
\hline $\begin{array}{l}\text { Dehydrogenase } \\
\left(\mu \mathrm{g} \text { TPF } g^{-1} h^{-1}\right)\end{array}$ & 9.29 & 9.57 & 3.01 & 7.57 & 7.71 & 1.85 \\
\hline $\begin{array}{c}\text { Phosphatase } \\
\left(\mu \mathrm{g} \text { PNP g }^{-1} \mathbf{h}^{-1}\right)\end{array}$ & 87.43 & 88.14 & 0.81 & 72.29 & 73.00 & 0.98 \\
\hline $\begin{array}{c}\text { Urease } \\
\left(\mu \mathrm{g} \mathrm{NH}{ }^{+} \mathrm{g}^{-1} \mathrm{~h}^{-1}\right)\end{array}$ & 7.29 & 7.57 & 3.84 & 5.57 & 5.71 & 2.51 \\
\hline
\end{tabular}

Table.4 Soil enzymatic activities under ZBNF and CF systems during 2019-20

\begin{tabular}{|c|c|c|c|c|c|c|}
\hline \multirow[t]{3}{*}{ Enzymes } & \multicolumn{6}{|c|}{ Farming systems } \\
\hline & \multicolumn{2}{|c|}{ ZBNF } & \multirow{2}{*}{ 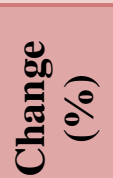 } & \multicolumn{2}{|c|}{ CF } & \multirow{2}{*}{ 总 } \\
\hline & $\begin{array}{l}\text { Before } \\
\text { sowing }\end{array}$ & $\begin{array}{c}\text { After } \\
\text { harvest }\end{array}$ & & $\begin{array}{l}\text { Before } \\
\text { sowing }\end{array}$ & $\begin{array}{c}\text { After } \\
\text { harvest }\end{array}$ & \\
\hline $\begin{array}{l}\text { Dehydrogenase } \\
\left(\mu \mathrm{g} \text { TPF } g^{-1} h^{-1}\right)\end{array}$ & 9.71 & 11.14 & 14.73 & 8.29 & 8.57 & 3.38 \\
\hline $\begin{array}{c}\text { Phosphatase } \\
\left(\mu \mathrm{g} \text { PNP } \mathrm{g}^{-1} \mathrm{~h}^{-1}\right)\end{array}$ & 90.71 & 92.00 & 1.42 & 72.86 & 73.86 & 1.37 \\
\hline $\begin{array}{c}\text { Urease } \\
\left(\mu \mathrm{g} \mathrm{NH}{ }^{+} \mathrm{g}^{-1} h^{-1}\right)\end{array}$ & 7.14 & 8.14 & 14.01 & 5.71 & 6.00 & 5.08 \\
\hline
\end{tabular}

Table.5 Soil arthropods population per $\mathrm{m}^{2}$ of soil (0-15 $\mathrm{cm}$ depth) under ZBNF and CF systems during 2018-19

\begin{tabular}{|l|c|c|c|c|c|c|}
\hline \multirow{2}{*}{ Orders } & \multicolumn{7}{|c|}{ Farming systems } \\
\cline { 2 - 7 } & \multicolumn{2}{|c|}{ ZBNF } & Change (\%) & \multicolumn{2}{c|}{ CF } & Change (\%) \\
\cline { 2 - 7 } & $\begin{array}{c}\text { Before } \\
\text { sowing }\end{array}$ & $\begin{array}{c}\text { After } \\
\text { harvest }\end{array}$ & & $\begin{array}{c}\text { Before } \\
\text { sowing }\end{array}$ & $\begin{array}{c}\text { After } \\
\text { harvest }\end{array}$ & \\
\hline Hymenoptera & 397.8 & 663 & 66.6 & 265.2 & 397.8 & 50 \\
\hline Hemiptera & 265.2 & 265.2 & 0 & 132.6 & 132.6 & 0 \\
\hline Coleoptera & 132.6 & 265.2 & 100 & 132.6 & 132.6 & 0 \\
\hline Isoptera & 397.8 & 530.4 & 33.3 & 265.2 & 397.8 & 50 \\
\hline Prostigmata & 265.2 & 132.6 & -50 & 265.2 & 265.2 & 0 \\
\hline Isopoda & 132.6 & 397.8 & 200 & 132.6 & 265.2 & 100 \\
\hline
\end{tabular}


Table.6 Soil arthropods population per $\mathrm{m}^{2}$ of soil $(0-15 \mathrm{~cm}$ depth) under ZBNF and CF systems during 2019-20

\begin{tabular}{|l|c|c|c|c|c|c|}
\hline \multirow{2}{*}{ Orders } & \multicolumn{7}{|c|}{ Farming systems } \\
\cline { 2 - 7 } & \multicolumn{2}{|c|}{ ZBNF } & Change (\%) & \multicolumn{2}{c|}{ CF } & Change (\%) \\
\cline { 2 - 7 } & $\begin{array}{c}\text { Before } \\
\text { sowing }\end{array}$ & $\begin{array}{c}\text { After } \\
\text { harvest }\end{array}$ & & $\begin{array}{c}\text { Before } \\
\text { sowing }\end{array}$ & $\begin{array}{c}\text { After } \\
\text { harvest }\end{array}$ & \\
\hline Hymenoptera & 928.2 & 1591.2 & 71.4 & 530.4 & 795.6 & 50 \\
\hline Hemiptera & 265.2 & 397.8 & 50 & 265.2 & 265.2 & 0 \\
\hline Coleoptera & 397.8 & 928.2 & 133.3 & 265.2 & 530.4 & 100 \\
\hline Isoptera & 397.8 & 530.4 & 33.3 & 530.4 & 663 & 25 \\
\hline Prostigmata & 265.2 & 265.2 & 0 & 132.6 & 265.2 & 100 \\
\hline Isopoda & 397.8 & 663 & 66.7 & 265.5 & 397.8 & 50 \\
\hline Geomorpha & 132.6 & 397.8 & 200 & 0 & 0 & 0 \\
\hline
\end{tabular}

The results clearly showed that the cow urine and dung based organic formulations resulted in higher microbial population, which is an indicator of healthy soil. Vishwajeet (2020) also reported increase of $3.83,10.46$ and 7.54 per cent in population of bacteria, fungi and actinomycetes, respectively, under Subhash Palekar Natural Farming (SPNF) system, whereas, in $\mathrm{CF}$ system the corresponding values were $4.35,15.54$ and 5.57 per cent. Rana (2019) also recorded 3.03, 12.5 and 12.4 per cent increase in bacteria, fungi and actinomycetes population under ZBNF system, whereas, in CF system the corresponding change was 1.72, 4.44 and 5.96 per cent. Gangadhar et al., (2020) reported higher bacterial population with Jeevamrit $\left(28.27 \times 10^{5}\right.$ and $31.59 \times 10^{5} \mathrm{CFU} \mathrm{g}^{-1}$ of soil, respectively) as compared to NCOFdecomposer $\left(21.54\right.$ and $23.73 \times 10^{5} \mathrm{CFU} \mathrm{g}^{-1}$ of soil, respectively) in two different seasons. Puneet and Saini (2009) also reported effect of five per cent jeevamriton microbial population and found significantly higher colony forming units (cfu) of bacteria (32.69 $\left.\times 10^{6}\right)$, fungi $\left(24.86 \times 10^{3}\right)$ and actinomycetes $\left(6.02 \times 10^{2}\right)$. Sreenivasa et al., (2009) recorded the microbial load of beejamrit and observed bacteria, fungi and actinomycetes were $15.4 \times 10^{5}, 10.5 \times 10^{3}$ and $6.8 \times 10^{3} \mathrm{cfu}$ respectively. Devakumar et al., (2018) also recorded higher bacteria, fungi and actinomycetes $40.33 \times 10^{5} \mathrm{CFU} / \mathrm{g}, \quad 20.33 \times 10^{4}$ $\mathrm{CFU} / \mathrm{g}$ and $15.33 \times 10^{3} \mathrm{CFU} / \mathrm{g}$ in jeevamrit. Our results are in line with the reported studies and show the beneficial effect of ZBNF in increasing the microbial population and biodiversity, which are important indicators of soil quality. Jeevamrit, ghanjeevamrit and beejamrit are effective formulations to for improving soil biological properties and ameliorate the soils.

Effect of beejamrit, Jeevamrit and ghanjeevamrit on soil enzymes over conventional practices

During 2018-19, dehydrogenase activity was $9.57 \mu \mathrm{g}$ TPF $\mathrm{g}^{-1} \mathrm{~h}^{-1}$ after harvest as compared to $9.29 \mu \mathrm{g}$ TPF g ${ }^{-1} \mathrm{~h}^{-1}$ at the time of sowing in ZBNF system, whereas in CF system, dehydrogenase activity (DHA) was $7.57 \mu \mathrm{g}$ TPF $\mathrm{g}^{-1} \mathrm{~h}^{-1}$ at the time of sowing and $7.71 \mu \mathrm{g}$ TPF $\mathrm{g}^{-1} \mathrm{~h}^{-1}$ at the end of the cropping season. The per cent increase was higher in ZBNF system $(3.01 \%)$ as compared to $\mathrm{CF}$ system (1.85\%) (Table 3). During 2019-20, the dehydrogenase was higher at harvest $(11.14$ $\mu \mathrm{g}$ TPF $\mathrm{g}^{-1} \mathrm{~h}^{-1}$ ) as compared to the value at the time of sowing $\left(9.71 \mu \mathrm{g}\right.$ TPF $\left.\mathrm{g}^{-1} \mathrm{~h}^{-1}\right)$ in ZBNF system. While in CF system, dehydrogenase activity was $8.29 \mu \mathrm{g}$ TPF $\mathrm{g}^{-1}$ 
$\mathrm{h}^{-1}$ initially at the time of sowing and increased to $8.57 \mu \mathrm{g}$ TPF $\mathrm{g}^{-1} \mathrm{~h}^{-1}$ at the end of the cropping season. The per cent increase was higher in ZBNF system (14.73\%), as compared to $\mathrm{CF}$ system $(3.38 \%)$ (Table 4). During first season, the phosphatase enzyme activity was higher at harvest $(88.14 \mu \mathrm{g}$ PNP $\left.\mathrm{g}^{-1} \mathrm{~h}^{-1}\right)$ as compared to the value at the time of sowing (87.43 $\mu \mathrm{g}$ PNP $\mathrm{g}^{-1} \mathrm{~h}^{-1}$ ) in ZBNF system, whereas in CF system, phosphatase activity was $72.29 \mu \mathrm{g}$ PNP $\mathrm{g}^{-1} \mathrm{~h}^{-1}$ initially at the time of sowing and increased to $73.00 \mu \mathrm{g}$ PNP $\mathrm{g}^{-1} \mathrm{~h}^{-1}$ at the end of the cropping season. The per cent increase was lower in $\mathrm{ZBNF}$ system $(0.81 \%)$ as compared to CF system $(0.98 \%)$ (Table 3$)$. In the second season, the phosphatase enzyme activity was higher at harvest $\left(92 \mu \mathrm{g} \mathrm{PNP} \mathrm{g}{ }^{-1} \mathrm{~h}^{-1}\right)$ as compared to the value at the time of sowing $\left(90.71 \mu \mathrm{g} \mathrm{PNP} \mathrm{g}^{-1}\right.$ $\mathrm{h}^{-1}$ ) in ZBNF system, whereas in CF system, phosphatase activity was $72.86 \mu \mathrm{g}$ PNP $\mathrm{g}^{-1} \mathrm{~h}$ initially at the time of sowing and increased to $73.86 \mu \mathrm{g}$ PNP $\mathrm{g}^{-1} \mathrm{~h}^{-1}$ at the end of the cropping season. The per cent increase was higher in ZBNF system (1.42\%) as compared to CF system (1.37\%) (Table 4). In case of the urease enzyme activity was higher at harvest during first season $\left(7.57 \mu \mathrm{g} \mathrm{NH}_{4}{ }^{+} \mathrm{g}^{-1} \mathrm{~h}^{-1}\right)$ as compared to the value at the time of sowing (7.29 $\mu \mathrm{g} \mathrm{NH}_{4}^{+} \mathrm{g}^{-1} \mathrm{~h}^{-1}$ ) in ZBNF system, whereas in $\mathrm{CF}$ system, urease enzyme activity was $5.57 \mu \mathrm{g} \mathrm{NH}_{4}^{+} \mathrm{g}^{-1} \mathrm{~h}^{-1}$ initially at the time of sowing and increased to $5.71 \mu \mathrm{g} \mathrm{NH}_{4}{ }^{+} \mathrm{g}^{-1} \mathrm{~h}^{-1}$ at the end of the cropping season.

The per cent increase was higher in $\mathrm{ZBNF}$ system (3.84\%), as compared to $\mathrm{CF}$ system (2.51\%) (Table 3). In second season urease enzyme activity was higher at harvest $(8.14$ $\mu \mathrm{g} \mathrm{NH}{ }_{4}^{+} \mathrm{g}^{-1} \mathrm{~h}^{-1}$ ) as compared to the value at the time of sowing $\left(7.14 \mu \mathrm{g} \mathrm{NH}_{4}^{+} \mathrm{g}^{-1} \mathrm{~h}^{-1}\right)$ in ZBNF system, whereas, in CF system, urease activity was $5.71 \mu \mathrm{g} \mathrm{NH}_{4}^{+} \mathrm{g}^{-1} \mathrm{~h}^{-1}$ initially at the time of sowing and increased to $6 \mu \mathrm{g}$ $\mathrm{NH}_{4}{ }^{+} \mathrm{g}^{-1} \mathrm{~h}^{-1}$ at the end of the cropping season. The per cent increase was higher in ZBNF system (14.01\%), as compared to CF system $(5.08 \%)$ (Table 4).

Vishwajeet (2020) also recorded beneficial effect of natural farming formulations on soil enzymatic activity in brinjal ecosystem. He reported23.79, 2.77 and 13.31 per cent increase in the soil activity of dehydrogenase, phosphatase and urease enzymes under SPNF system, whereas, the corresponding value of CF system were $10.11,0.72$ and 17.03 per cent, respectively. Rana (2019) reported similar results in cabbage grown under ZBNF, with $37.29,7.31$ and 10.51 per cent increase in activity of dehydrogenase, phosphatase and urease enzymes in ZBNF system, whereas the corresponding value of CF system were 4.65 , 1.37 and 5.78 per cent, respectively. Verma et $a l$. , (2018) reported that DHA increased from 6.9 $\mu \mathrm{g}$ TPF $\mathrm{g}^{-1} \mathrm{~h}^{-1}$ under CF to 7.3 $\mu \mathrm{g}$ TPF $\mathrm{g}^{-1}$ $\mathrm{h}^{-1}$ under Organic Farming and was highest under ZBNF i.e. 8.4 $\mu \mathrm{g}$ TPF $\mathrm{g}^{-1} \mathrm{~h}^{-1}$. Similarly alkaline and acid phosphatase activity in $\mathrm{ZBNF}$, the alkaline phosphatase activity increased to $105 \mu \mathrm{g} \mathrm{PNP} \mathrm{g} \mathrm{g}^{-1} \mathrm{~h}^{-1}$ in comparison to $65 \mu \mathrm{g}$ PNP g $\mathrm{g}^{-1} \mathrm{~h}^{-1}$ and $71 \mu \mathrm{g}$ PNP $\mathrm{g}^{-1} \mathrm{~h}^{-1}$ under Conventional and Organic Farming systems, respectively. The acid phosphatase

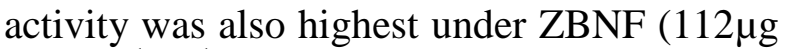
PNP $\mathrm{g}^{-1} \mathrm{~h}^{-1}$ ) followed by Organic Farming $\left(99 \mu \mathrm{g} \mathrm{PNP} \mathrm{g}^{-1} \mathrm{~h}^{-1}\right)$ and CF $\left(84 \mu \mathrm{g} \mathrm{PNP} \mathrm{g}^{-1} \mathrm{~h}^{-1}\right)$. Gangadhar et al., (2020) also provided a supportive base to our study with dehydrogenase activity (53.70 TPF formed $\mathrm{g}^{-1}$ soil day $\left.^{-1}\right)$, acid phosphatase activity (31.35 PNP formed $\mathrm{g}^{-1}$ soil hour $\left.{ }^{-1}\right)$, alkaline phosphatase activity (21.66 PNP formed g-1 soil hour ${ }^{-1}$ ) and urease activity (5.97 g NH4-N formed $\mathrm{g}^{-1}$ soil hour $\left.^{-1}\right)$ in jeevamrit formulations. Soil enzymes are the basic degradation unit in soil, if their activity reduced that reduces the availability of nutrients in soil. We can justify the importance of soil enzymes and their availability in these indigenous organic formulations by our study. Clearly the 
recommendation of these formulations will benefit the farmers with long and prosper soil qualities.

\section{Effect on soil arthropods}

During 2018-19, the first year of experiment, the data recorded showed an increase in soil arthropods population. Under ZBNF, an increase of66.6, 100, 33.3 and 200 per cent in Hymenoptera, Coleoptera, Isoptera, and Isopoda, respectively, were observed. The Prostigmata population showed a decrease of 50 per cent. Under CF system, the Hymenoptera, Isoptera, and Isopodapopulation increased by 50,50 and 100 per cent (Table 5). During 2019-20, the soil population of Hymenoptera, Hemiptera, Coleoptera, Isoptera, Isopoda and Geomorpha increased by71.4, 50, 133.33, 33.3, 66.7 and 200 per centunder ZBNF system, while under CF system, the population of Hymenoptera, Coleoptera, Isoptera, Prostigmata and Isopoda were 50, 100, 25, 100 and 50 per cent (Table $6)$.

During the experimental period the diversity of soil arthropods were almost similar in ZBNF and CF systems, but in ZBNF system, one additional species was found, which belong to the order Geomorpha. Pahari et al., (2007) recorded order Acari had maximum dominance $(47.04 \%)$, followed by Collembola (38.68\%), Hymenoptera (3.40\%), Coleoptera (3.3\%), Diplura (1.81\%), Diplopoda (1.49\%), Isopoda (1.27\%), Aranea $(1.20 \%)$, Chilopoda (1.00\%), Dermaptera $(0.49 \%)$. The order Diptera had minimum dominance $(0.26 \%)$. Simoni et al., (2013) recorded arthropod density ranged from about 20,000 individuals $/ \mathrm{m}^{2}$ in 16 years old field to about 45,000 in 6 year's old field and recorded higher population of mites. Soil arthropods not only help in improvement of soil quality but also help in reduction of pest population. Generally decomposer and predator arthropods increase due to application of organic formulations as compare to conventional practices.

\section{References}

Bano R and Roy S. 2016. Extraction of soil microarthropods: A low cost BerleseTullgren funnels extractor. International Journal of Fauna and Biological Studies3(2): 14-17.

Daikh, EB, EL-Mabrouk, A. and EL Roby, A. S. M. H. (2016). Effect of glyphosate herbicide on the behavior of soil arthropods in non-organic tomato system.Advance agriculture biology. 5(1): $1-15$.

Devakumar N, Lavanya G and Rao GGE. 2018. Influence of Jeevamrutha and Panchagavya on beneficial soil microbial population and yield of organic fieldbean (Dolichos lablab L.). Mysore Journal of Agricultural Sciences, 52(4): 790-795.

Devakumar N, Shubha S, Gouder SB and Rao GGE. 2014. Microbial analytical studies of traditional organic preparations beejamrutha and jeevamrutha.

Gangadhar K, Devakumar N, Vishwajith and Lavanya G. 2020. Influence of different sources of organic manures and decomposers on enzymatic activity and microbial dynamics of rhizosphere soil of chilli (Capsicum annum L.). International Journal of Current Microbiology and Applied Sciences, 9(1): 542-555.

Ghosal A. and Hati A. (2019). Impact of some new generation insecticides on soil arthropods in rice maize cropping system.The Journal of Basic and Applied Zoology. 80(6): 1-8.

Henneron L., Bernard L., Hedde M., Pelosi C., Villenave C., Chenu C., Bertrand M., Girardin C. and Blanchart E. (2015). Fourteen years of evidence for positive effects of conservation agriculture and organic farming on soil life. Agronomic Sustainable Development.35:169-181.

Pahari D, Hazra AK and Saha GK. 2007. 
Diversity and distribution of soil arthropod communities in relation to altitude and edaphic factors of different altitudinal environments of Darjeeling Himalayas, India. Rec. Zool. surv. India, 107: 43-59.

Parisi V, Menta C, Gardi C, Jacomini C and Mozzanica E. 2005. Microarthropod communities as a tool to assess soil quality and biodiversity: a new approach in Italy. Agriculture, Ecosystems and Environment, 105: 323-333.

Puneet K and Saini JP. 2009. Standardization of the doses and time of application of 'Jeevamrit' in wheat under natural farming system. M.Sc., Thesis. CSKHPKV, Palampur.

Rana A. 2019. Insect-pests, natural enemies and soil micro-flora in cabbage under Zero Budget Natural Farming and Conventional Farming systems. M. ScThesis. Dr YS Parmar University of Horticulture and Forestry, Nauni, Solan (HP).

Shubha S, Devakumar N, Rao GGE and Gowda SB. 2014.Effect of seed treatment, panchagavya application and organic farming systems on soil microbial population, growth and yield of maize.

Shubha S, Devakumar N, Rao GGE and Gowda SB. 2014.Effect of seed treatment, panchagavya application and organic farming systems on soil microbial population, growth and yield of maize.

Simoni S, Nannelli R, Castagnoli M, Goggioli D, Moschini V, Vazzana C, Benedettelli S and Migliorini P. 2013. Abundance and biodiversity of soil arthropods in one conventional and two organic fields of maize in stockless arable systems.REDIA96: 37-44.

Singh AS and Lal EP. 2019. Impact of organic liquid formulation, jeevamrutha on photosynthetic pigments of Ocimum basilicum L. (sweet basil) under $\mathrm{NaCl}$ induced salinity stress. Plant archives 19: 1997-2001.

Sreenivasa MN, Naik N and Bhat SN. 2009. Beejamrutha: A source for beneficial bacteria. Karnataka J. Agric. Sci., 22(5): 1038-1040.

Tabatabai MA and Bremner JM. 1969. Use of p-nitrophenyl phosphate for assay of soil phosphatase activity. Soil biology and biochemistry, 1: 301-317.

Thimmaiah SR. 1999. Standard methods of biochemical analysis. Kalyani publishers, New Delhi, India. 545p.

Verma S, Chandel RS, Kaushal R, Yankit P and Sharma S. 2018. Soil quality management through Zero Budget Natural Farming.https://www.icar.org.in/content/v olume-24-no-3-july-september-2018 [11:30AM, $16^{\text {th }}$ August 2018].

Vishwjeet. 2020. Population dynamics of insect-pests of brinjal and their natural enemies under SubhashPalekar Natural Farming and Conventional Farming systems. M.Sc., Thesis. Dr. YS Parmar University of Horticulture and Forestry, Nauni, Solan (HP).

Zhen Z, Liu H, Wang N, Guo L, Meng J, Ding $\mathrm{N}, \mathrm{Wu} \mathrm{G}$ and Jiang G. 2014. Effects of manure compost application on soil microbial community diversity and soil microenvironments in a temperate cropland in China. Plos one9(10): 1-12.

\section{How to cite this article:}

Abdul Wakil Barakzai, Rajeshwar Singh Chandel, Sudhir Verma, PremLal Sharma, Narendra Kumar Bharat, Maneesh Pal Singh and Panma Yankit. 2021. Effect of Zero Budget Natural Farming and Conventional Farming Systems on Biological Properties of Soil. Int.J.Curr.Microbiol.App.Sci. 10(02): 1122-1129. doi: https://doi.org/10.20546/ijcmas.2021.1002.132 